\title{
Understanding of the Fate of Atmospheric Pollutants Using a Process Analysis Tool in a 3-D Regional Air Quality Model at a Fine Grid Scale
}

\author{
Yang Zhang $^{1^{*}}$, Shiang-Yuh Wu ${ }^{2}$ \\ ${ }^{1}$ Department of Marine, Earth and Atmospheric Sciences, North Carolina State University, Raleigh, USA \\ ${ }^{2}$ Department of Air Quality and Environmental Management, Las Vegas, USA \\ Email: *yang_zhang@ncsu.edu
}

Received October 16, 2012; revised November 18, 2012; accepted November 26, 2012

\begin{abstract}
The process analysis is performed for August and December, 2002 using the process analysis tool embedded in the Community Multiscale Air Quality (CMAQ) modeling system at a fine horizontal grid resolution of 4-km over an area in the southeastern US that is centered at North Carolina. The objectives are to qunatify the contributions of major atmospheric processes to the formation of major air pollutants and provide the insights into photochemistry that governs the fate of these pollutants at a fine grid scale. The results show that emissions provide a dominant source for gases including ammonia $\left(\mathrm{NH}_{3}\right)$, nitric oxide $(\mathrm{NO})$, nitrogen dioxide $\left(\mathrm{NO}_{2}\right)$, and sulfur dioxide $\left(\mathrm{SO}_{2}\right)$ and Particulate Matter $(\mathrm{PM})$ species including fine $\mathrm{PM}\left(\mathrm{PM}_{2.5}\right)$ and its composition such as sulfate, elemental carbon, primary organic aerosol, and other inorganic fine $\mathrm{PM}$ in both months. While transport acts as a major sink for $\mathrm{NH}_{3}, \mathrm{NO}$, and $\mathrm{SO}_{2}$ at most sites and $\mathrm{PM}_{2.5}$ and most of $\mathrm{PM}_{2.5}$ composition at urban sites, it provides a major source for nitric acid $\left(\mathrm{HNO}_{3}\right)$ and ozone $\left(\mathrm{O}_{3}\right)$ at most sites in both months, and secondary PM species in August and most PM species in December at rural and remote sites. Gas-phase chemistry serves as a source for $\mathrm{NO}_{2}$ and $\mathrm{HNO}_{3}$ but a sink for $\mathrm{O}_{3}$ at urban and suburban sites and for $\mathrm{NO}$ and $\mathrm{SO}_{2}$ at all sites. $\mathrm{PM}$ processes contribute to the formation of $\mathrm{PM}_{2.5}$ and nitrate $\left(\mathrm{NO}_{3}^{-}\right)$at the urban and suburban sites and secondary organic aerosol (SOA) at most sites in December and ammonium $\left(\mathrm{NH}_{4}^{+}\right)$in both months. They reduce $\mathrm{NO}_{3}^{-}$formation at most sites in August and at rural and remote sites in December and the formation of $\mathrm{PM}_{2.5}$ and SOA at most sites in August. Dry deposition is an important sink for all these species in both months. The total odd oxygen $\left(\mathrm{O}_{\mathrm{x}}\right)$ production and the total hydroxyl radical $(\mathrm{OH})$ reacted are much higher at urban and suburban sites than at rural sites. Significant amounts of $\mathrm{OH}$ are consumed by biogenic volatile organic compounds (BVOCs) in the rural and remote areas and a combination of anthropogenic VOCs (AVOCs) and BVOCs in urban and subareas areas in August and mainly by AVOCs in December. The amount of $\mathrm{NO}_{2}$ produced by the reactions of hydroperoxy radical $\left(\mathrm{HO}_{2}\right)$ is similar to that of organic peroxy radical $\left(\mathrm{RO}_{2}\right)$ at all sites in August but higher than that by the reactions of $\mathrm{RO}_{2}$ in December. The production rate of $\mathrm{HNO}_{3}$ due to the reaction of $\mathrm{OH}$ with $\mathrm{NO}_{2}$ dominates in both months. The ratio of the production rates of hydrogen peroxide $\left(\mathrm{H}_{2} \mathrm{O}_{2}\right)$ and $\mathrm{HNO}_{3}\left(\mathrm{PH}_{2} \mathrm{O}_{2} / \mathrm{PHNO}_{3}\right)$ is a more robust photochemical indicator than the ratios of their mixing ratios $\left(\mathrm{H}_{2} \mathrm{O}_{2} / \mathrm{HNO}_{3}\right)$ and the afternoon mixing ratios of $\mathrm{NO}_{\mathrm{y}}$ in both months, and it is highly sensitive to the horizontal grid resolution in August. The use of $\mathrm{PH}_{2} \mathrm{O}_{2} / \mathrm{PHNO}_{3}$ simulated at 4-km indicates a VOC-limited $\mathrm{O}_{3}$ chemistry in urban and suburban areas in August that was not captured in previous model simulations at a coarser grid resolution.
\end{abstract}

Keywords: Air Pollutants; Process Analysis; Photochemical Indicator; MM5; CMAQ

\section{Introduction}

Process Analysis (PA) is a useful tool embedded in a 3-D air quality model that calculates the Integrated Process Rates (IPR) for major atmospheric processes such as emissions, chemical reactions, horizontal and vertical transport, and removal processes and the Integrated Re-

"Corresponding author. action Rates (IRR) for all gas-phase chemical reactions in all model grid cells. The results from IPR provide the relative contributions of individual physical and chemical processes to the formation of gas and Particulate Matters (PM) species. These processes include emissions, vertical and horizontal transport, gas-phase chemistry, PM processes, aqueous-phase processes (or cloud processes), and dry deposition. The results from IRR provide individual 
gas-phase reaction rates that can be used to identify key chemical pathways for ozone $\left(\mathrm{O}_{3}\right)$ and its precursors, the chemical regimes of $\mathrm{O}_{3}$, as well as gaseous precursors of secondary PM with aerodynamic diameter less than and equal to $2.5 \mathrm{~m}\left(\mathrm{PM}_{2.5}\right)$ [1-3]. For example, the net production and loss of total odd oxygen $\left(\mathrm{O}_{\mathrm{x}}\right)$ represent the total oxidation capacity that affects the formation efficiency of $\mathrm{O}_{3}$ and secondary PM. The list of typical IRR products can be found in Zhang et al. [3]. PA has been conducted in several studies to quantify the contributions of atmospheric processes and chemical reactions to the formation of $\mathrm{O}_{3}$ and $\mathrm{PM}_{2.5}$ [e.g., 3-9]. All those studies focused only criteria pollutants such as $\mathrm{O}_{3}$ and $\mathrm{PM}_{2.5}$ and used a horizontal grid resolution of $36-\mathrm{km}$ or coarser. Very few studies include PA for agriculturally-emitted pollutants such as ammonia $\left(\mathrm{NH}_{3}\right)$ and ammonium $\left(\mathrm{NH}_{4}^{+}\right)$ and are performed at a horizontal grid spacing of $4-12$ $\mathrm{km}$.

In this study, 3-D model simulations and PA are conducted at a horizontal grid spacing of $4-\mathrm{km}$ to simulate $\mathrm{O}_{3}$, PM, and their precursors. The objective of this study is to identify the governing atmospheric processes of major air pollutants including both creteria and noncreteria air pollutants and associated seasonalities at a fine grid resolution. An area in the southeastern US that centers over North Carolina (NC) is selected for this study. This area feasures with very high emissions of $\mathrm{NH}_{3}$ from agricultural livestock, which account for about 91\% (i.e., 482.9 tons $\cdot$ day $^{-1}$ ) in August and 81\% (i.e., 253.4 tons $\cdot$ day $^{-1}$ ) in December of total $\mathrm{NH}_{3}$ emissions [10]. PA over this area allows an understanding of the fate of non-creteria pollutants such as $\mathrm{NH}_{3}, \mathrm{NH}_{4}^{+}$, nitric acid $\left(\mathrm{HNO}_{3}\right)$, and reduced nitrogen $\left(\mathrm{NH}_{\mathrm{x}}=\mathrm{NH}_{3}+\mathrm{NH}_{4}^{+}\right)$, in addition to that of creteria air pollutants such as nitric oxide $(\mathrm{NO})$, nitrogen dioxide $\left(\mathrm{NO}_{2}\right)$, sulfur dioxide $\left(\mathrm{SO}_{2}\right)$, $\mathrm{O}_{3}$, and $\mathrm{PM}_{2.5}$.

\section{Modeling Domain and Simulation Setup}

The modeling system consists of the Pennsylvania State University (PSU)/National Center for Atmospheric Research (NCAR) Mesoscale Modeling System Generation 5 (MM5) version 3.7 [11], the Sparse Matrix Operator Kernel Emissions (SMOKE) Modeling System version 2.1 [12], and the Community Multiscale Air Quality (CMAQ) modeling system version 4.4 [13]. The PA tool embedded in CMAQ is used to quantify the contributions of major atmospheric processes of major air pollutants. The 3-D model simulations are conducted for August and December of 2002 at a 4-km horizontal grid spacing over a domain that covers nearly the entire state of $\mathrm{NC}$, and a portion of several adjacent states including South Carolina (SC), Georgia (GA), Tennessee (TN), West Virginia (WV), and Virginia (VA), as shown in Figure 1. This area consists of three well-developed physiographic divisions from east to west: the Coastal Plain, the Pidemont, and the Mountains. The complex topography and weather patterns as well as a combination of industrial, agricultural, traffic, and biogenic emissions make this area one of the most complex and representative airsheds in the US.

The model input files for initial and boundary conditions (ICs and BCs) and meteorology at a 4-km horizontal grid spacing are developed based on the MM5/CMAQ model simulations at a $12-\mathrm{km}$ horizontal grid spacing obtained from the Visibility Improvement State and Tribal Association of the Southeast's (VISTAS) 2002 modeling program (http://www.vista-sesarm.org.asp). For consistency, the model configurations and options for physics and chemistry for the MM5/CMAQ simulations at 4-km in this work are set to be the same as those used in the 2002 base year VISTAS Phase II modeling study at $12-\mathrm{km}$. The vertical resolution includes 19 layers from surface to the tropopause $(\sim 15 \mathrm{~km})$ with $\sim 38 \mathrm{~m}$ for the first layer height. The emission inventories for gaseous and PM species are based on the VISTAS 2002 emissions. As described in the work of $\mathrm{Wu}$ et al. [10], the model evaluation showed that MM5/CMAQ gave an overall good performance for meteorological variables and $\mathrm{O}_{3}$ mixing ratios and a reasonably good performance for $\mathrm{PM}_{2.5}$. A more detailed description of the model configurations, ICs and BCs, the databases used for the operational evaluation for meteorological and chemical predictions, and the model performance evaluation for both MM5 and CMAQ can be found in Wu et al. [10].

A detailed PA analysis is performed at 17 sites from three surface networks: seven sites from the Speciation Trends Network (STN): Kinston, Asheville, Hickory, Fayetteville, Winston-Salem, Charlotte, and Raleigh; four sites from the Interagency Monitoring of Protected Visual Environments (IMPROVE): GRSM1, LIGO1, SHRO1, and SWAN1; and six sites from the Clean Air Status

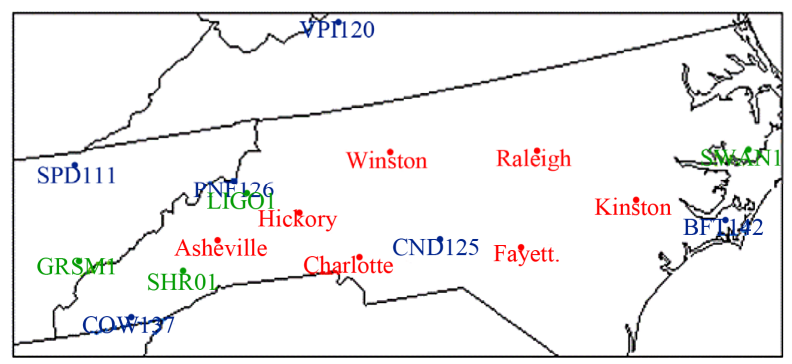

Figure 1. Simulation domain and locations of observational sites selected for process analysis, including seven STN sites (red): Kinston, Asheville, Hickory, Fayetteville, Winston-Salem, Charlotte, and Raleigh; four IMPROVE sites (green): GRSM1, LIGO1, SHRO1, and SWAN1; six CASTNET sites (blue): BFT142, CND125, COW137, PNF126, SPD111, and VPI120. 
Trends Network (CASTNET): BFT142, CND125, COW137, PNF126, SPD111, and VPI120. Their locations are shown in Figure 1. Among the STN sites, Kinston and Fayetteville are located in the Coastal Plain region, Ashville is located in the Mountains, and Hickory, WinstonSalem, Charlotte, and Raleigh are located in the Pidemont region. Among the IMPROVE sites, GRSM, LIGO1, and SHRO1 are located in the Mountains and SWAN1 is in the Coastal Plain region. Among the CASTNET sites, BFT142 is a Coastal Plain site, CND125 is a Pidemont site, and COW137, PNF126, SPD111, and VPI120 are all located in the Mountains.

\section{Process Analysis}

\subsection{Integrated Process Rates}

Figure 2 shows the monthly-mean contributions of individual processes to the mixing ratios of gaseous species in the surface layer at the 17 locations in August and December 2002. Emissions provide a dominant source of $\mathrm{NH}_{3}$ at all STN sites except for Asheville in August and at all STN sites in December. Among the 17 sites, the largest emissions occur at Kinston and Fayetteville where $\mathrm{NH}_{3}$ emissions from agricultural livestock are high. Transport reduces the mixing ratios of $\mathrm{NH}_{3}$ at most sites (except for CND125 in August), particularly at Kinston in August and at Kinstron, Fayetteville, and Charlotte in December. Dry deposition also acts as a sink for $\mathrm{NH}_{3}$ at all sites, particularly at Kinstron, Fayetteville, and CND125 in August and at Kinston in December. PM processes such as gas-to-particle mass transfer convert $\mathrm{NH}_{3}$ to $\mathrm{NH}_{4}^{+}$at most sites in both months. Emissions of NO are high in both months at all STN sites expect for Kinston, providing the main source of nitrogen oxides $\left(\mathrm{NO}_{\mathrm{x}}=\mathrm{NO}\right.$ $+\mathrm{NO}_{2}$ ) at these sites. Major loss processes of NO in both months include gas-phase chemistry (i.e., its titration reactions with $\mathrm{O}_{3}$ ) and horizontal and vertical transport. The same titration reaction of $\mathrm{NO}$ with $\mathrm{O}_{3}$ produces $\mathrm{NO}_{2}$, which is the most important source of $\mathrm{NO}_{2}$ at the STN sites in both months. Emissions of $\mathrm{NO}_{2}$ provide additional sources at several STN sites including Hickory, Fayetteville, Winston-Salem, and Charlotte. The major loss processes of $\mathrm{NO}_{2}$ in both months include transport at most sites, particularly at the STN sites, and dry deposition at all sites. Comparing to the STN sites, the process contributions to $\mathrm{NH}_{3}$ and $\mathrm{NO}_{\mathrm{x}}$ at the IMPROVE and CASTNET sites are relatively small, due to a lack of pollutant sources in the Costal Plain and mountain regions. While transport contributes to the accumulation of $\mathrm{HNO}_{3}$ at all 17 sites in August and at all sites except for Kinston, Hickory, and CND125 in December, dry deposition is a major sink of $\mathrm{HNO}_{3}$ at these sites. Cloud and PM processes also contribute to its sink in December. In August, emissions at all STN sites except for Kinston provide a major source of $\mathrm{SO}_{2}$, and transport is the main process to accumulate $\mathrm{SO}_{2}$ at the IMPROVE and CASTNET sites except for SWAN1 and COW137. While both dry deposition and transport are important sinks at the STN sites, dry deposition dominates the loss of $\mathrm{SO}_{2}$ at the IMPROVE and CASTNET sites. In December, emissions provide a main source of $\mathrm{SO}_{2}$ at all STN sites except for Kinston, Asheville, and Raleigh where transport is either a dominant source or equally important to its emissions. Transport also helps accumulation of $\mathrm{SO}_{2}$ at all IMPROVE and CASTNET sites. Dry deposition, gasphase chemistry, and cloud processes including aqueousphase chemistry and wet scavenging contribute to the loss of $\mathrm{SO}_{2}$ at all these sites. In August, $\mathrm{O}_{3}$ comes primarily from transport and it is lost due mainly to gasphase chemistry at Hickory, Fayetteville, and WinstonSalem, both gas-phase chemistry and dry deposition at Charlotte, and dry deposition at all remaining sites. In December, transport accumulates $\mathrm{O}_{3}$ at all STN sites except for Kinston, two IMRPOVE sites (LIGO1 and SHRO1) and one CASTNET site (PNF126). Gas-phase chemistry provides a major sink at all sites, in particular at all STN sites except for Kinston.

Figure 3 shows the monthly-mean contributions of individual processes to the mass concentrations of $\mathrm{PM}_{2.5}$ and its major composition including sulafte $\left(\mathrm{SO}_{4}^{2-}\right)$, $\mathrm{NH}_{4}^{+}$, nitrate $\left(\mathrm{NO}_{3}^{-}\right)$, elemental carbon (EC), primary organic aerosol (POA), secondary organic aerosol (SOA), and other inorganic fine PM (OIN) in the surface layer at the 17 sites. For $\mathrm{PM}_{2.5}$ in August, emissions provide a dominant source at all STN sites except for Kinston and transport helps its accumulation at three IMPROVE sites (i.e., GRSM, LIGO1, and SHRO1) and two CASTNET sites (i.e., PNF126 and VPI120). Transport is a major sink process at most STN sites and dry deposition contributes the most to the loss of $\mathrm{PM}_{2.5}$ at LIGO1, SHRO1, and PNF126. In December, both emissions and PM processes are important sources of $\mathrm{PM}_{2.5}$ at most STN sites, and transport helps its accumulation at GRSM, LIGO1, SHRO1, and PNF126. Transport plays a similar role to that in August, depleting $\mathrm{PM}_{2.5}$ at the STN sites. Dry deposition is a major sink of $\mathrm{PM}_{2.5}$ at several sites including Ashville, LIGO1, SHRO1, and PNF126. Cloud processes also contribute to the loss of $\mathrm{PM}_{2.5}$ at all sites in both months. For $\mathrm{NH}_{4}^{+}, \mathrm{PM}$ processes provide a dominant source at all sites in August and most sites in December. A more significant conversion of $\mathrm{NH}_{3}$ to $\mathrm{NH}_{4}^{+}$ occurs at Kinston in December than in August (40\% $60 \%$ vs $<20 \%-30 \%$ ) due to the formation of $\mathrm{NH}_{4} \mathrm{NO}_{3}$ under the favorable weather condition as shown in $\mathrm{Wu}$ et al. [10], leading to much higher contributions of PM processes to $\mathrm{NH}_{4}^{+}$at this site in December than in August. Transport causes the loss of $\mathrm{NH}_{4}^{+}$at the STN sites and several CASTNET sites in both months, but contributes 


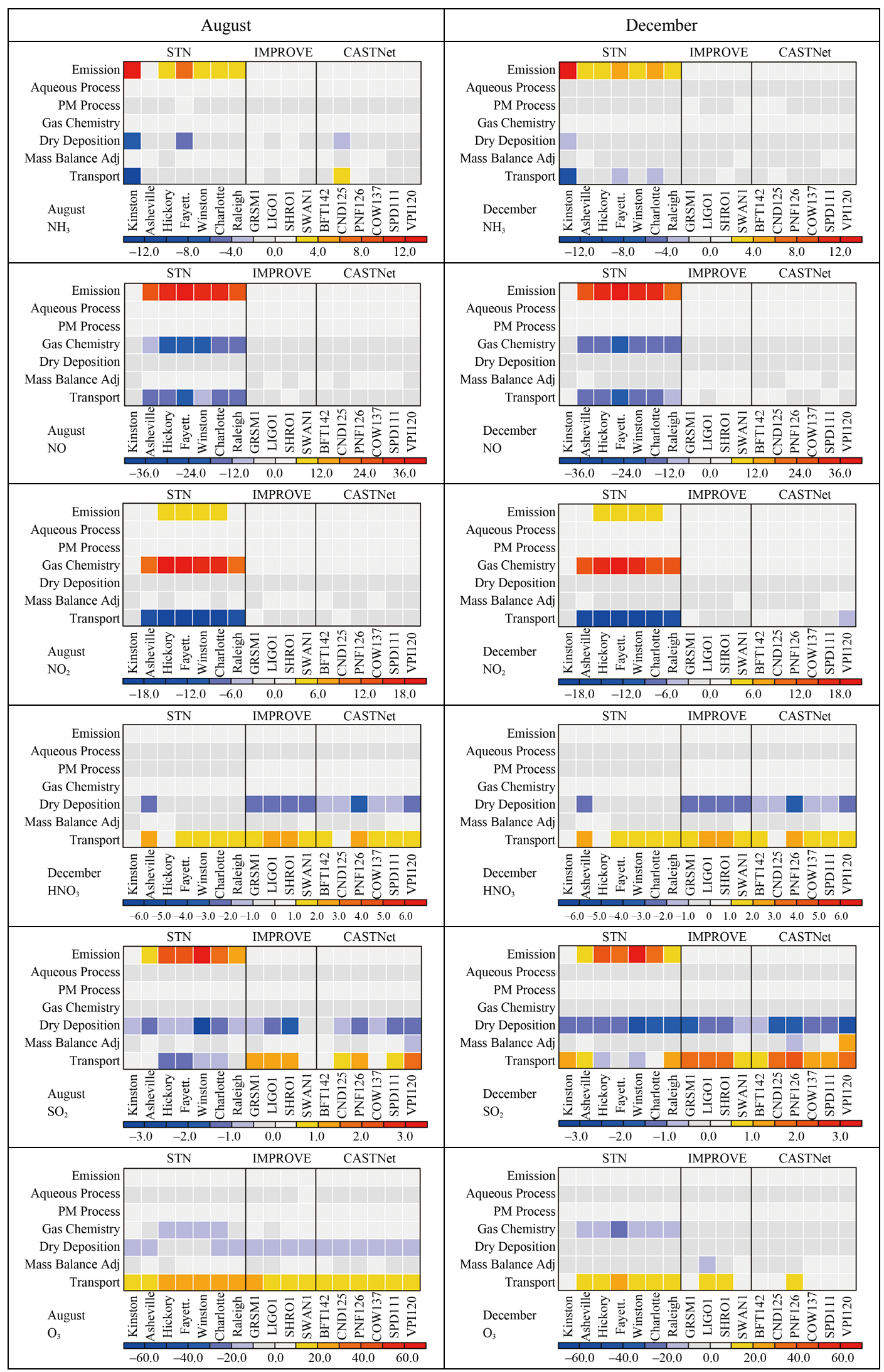

Figure 2. The monthly-mean process contributions to the surface mixing ratios of $\mathrm{NH}_{3}, \mathrm{NO}, \mathrm{NO}_{2}, \mathrm{HNO}_{3}, \mathrm{SO}_{2}$, and $\mathrm{O}_{3}$ in $\mathrm{ppb} \cdot \mathrm{hr}^{-1}$ during August and December 2002. 


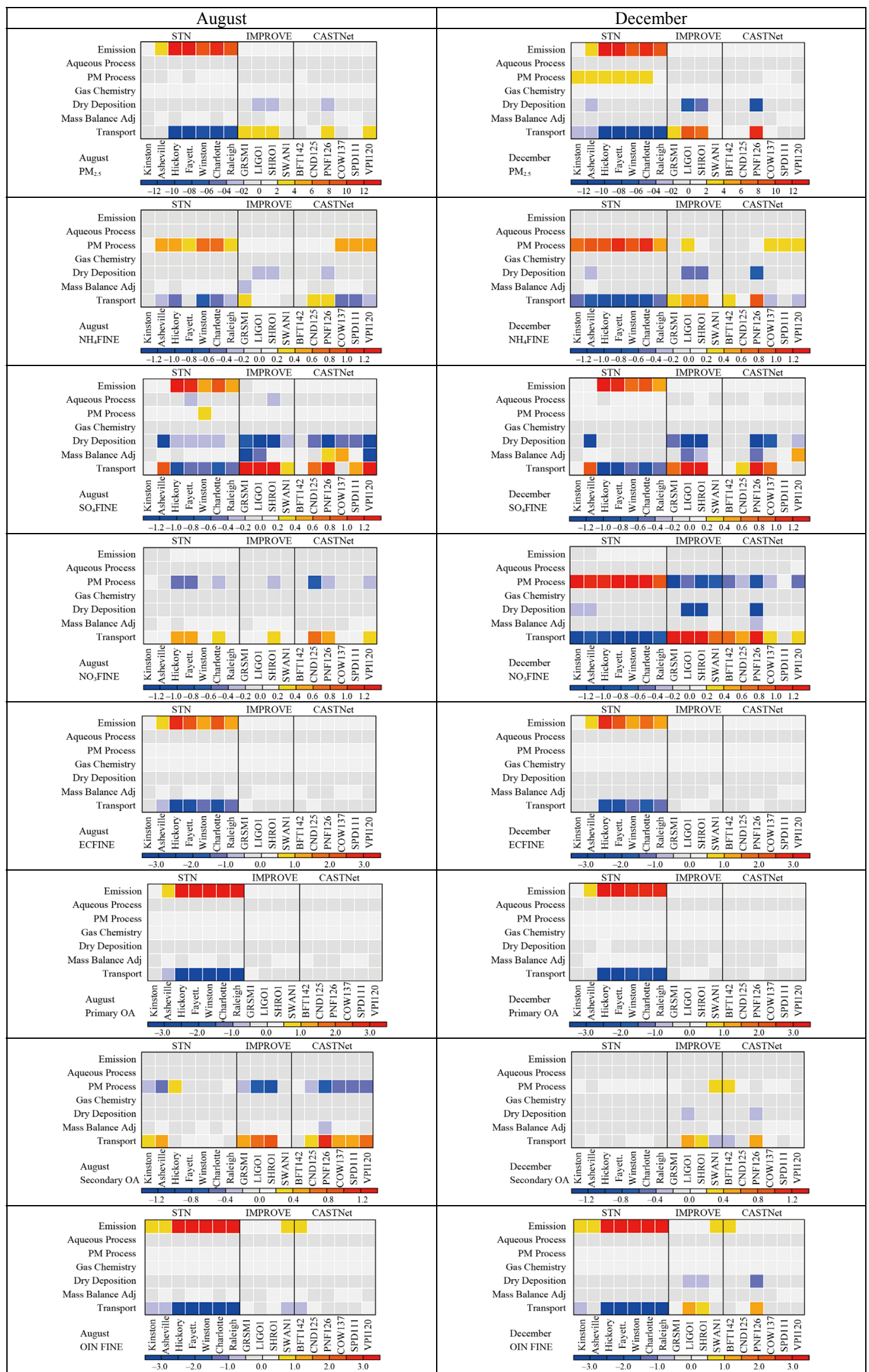

Figure 3. The monthly-mean process contributions to the surface concentrations of $\mathrm{PM}_{2.5}, \mathrm{NH}_{4}^{+}, \mathrm{SO}_{4}^{2-}, \mathrm{NO}_{3}^{-}, \mathrm{EC}, \mathrm{POA}$, SOA, and OIN in $\mu \mathrm{g} \cdot \mathrm{m}^{-3} \cdot \mathrm{hr}^{-1}$ during August and December 2002. 
to its accumulation at several other sites including GRSM, CND125, and PNF126 in August and GRSM, LIGO1, SHRO1, SWAN1, and PNF126 in December. For $\mathrm{SO}_{4}^{2-}$, the emissions provide a dominant source at all STN sites except for Ashville where transport provides the source in both months and Winston-Salem where PM processes such as homogeneous nucleation generate PM in August. Transport and dry deposition are major sink processes for $\mathrm{SO}_{4}^{2-}$ at most of these sites in both months, and cloud processes also contribute to its loss at all sites, particularly at Fayetteville in August, and at Hickory in December. At most IMPROVE and CASTNET sites, transport and dry deposition provide a dominant source and sink, respectively, for $\mathrm{SO}_{4}^{2-}$ in both months. Mass balance adjustment contributes to some losses of $\mathrm{SO}_{4}^{2-}$ at GRSM1, LIGO1, and VPI120 in August and at LIGO1, SHRO1, and PNF126 in December; it also contributes to some gains of $\mathrm{SO}_{4}^{2-}$ at PNF126 and COW137 in August and at VPI120. All of these sites are located in the Appalachian Mountains region. The relatively larger contributions of mass balance adjustment indicate the difficulty of MM5 in simulating advection and vertical mixing processes over complex terrains, which propagates into chemical predictions of CMAQ. $\mathrm{NO}_{3}^{-}$at all sites comes primarily from transport in August, and it is removed mainly through PM processes such as evaporation back to the gas-phase, aqueous processes such as aqueous-phase chemistry and wet scanvenging, and dry deposition. For comparison, in December, $\mathrm{NO}_{3}^{-}$at all STN sites is produced by PM processes such as the condensation of $\mathrm{HNO}_{3}$ but by transport at all other sites. $\mathrm{NO}_{3}^{-}$is reduced by transport at all STN sites and additionally by dry deposition at
Kinston and Asheville, but it is lost via PM processes such as the evaporation and coagulation at all IMPROVE and CASTNET sites (except for SPD111) and additionally by dry deposition at three mountain sites (i.e., LIGO1, SHRO1, and PNF126). The gain and loss of $\mathrm{NO}_{3}^{-}$in December show a strong correlation with those of $\mathrm{NH}_{4}^{+}$at all STN sites, indicating the formation of $\mathrm{NH}_{4} \mathrm{NO}_{3}$ under the favorable weather and chemical conditions at these sites. For EC, POA, and OIN, the main production and loss are emissions and transport, respectively, at most STN sites. OIN may also be produced by emissions at other sites such as SWAN1 and BFT142 in both months or LIGO1, SHRO1, and PNF126 in December. Different from POA, transport is a dominant source for SOA at most sites in August and December. Gas/particle mass transport is a major contributor to SOA formation at Hickory in August and SWAN1 and BFT142 in December.

Figure 4 shows the monthly-mean contributions of individual processes to the mass concentrations of reduced nitrogen $\left(\mathrm{NH}_{\mathrm{x}}=\mathrm{NH}_{3}+\mathrm{NH}_{4}^{+}\right)$and total nitrate $\left(\mathrm{TNO}_{3}=\right.$ $\mathrm{HNO}_{3}+\mathrm{NO}_{3}^{-}$) in the surface layer. The fate of $\mathrm{NH}_{\mathrm{x}}$ is dominated by that of $\mathrm{NH}_{3}$, with a major gain from emissions and a major loss by transport and deposition at most STN sites in both months. The fate of $\mathrm{TNO}_{3}$ is dominated by that of $\mathrm{HNO}_{3}$, with a major gain from transport and a major loss by deposition at all sites in both months.

\subsection{Integrated Reaction Rates (IRR)}

Figure 5 shows the spatial distributions of the monthlymean production and loss of $\mathrm{O}_{\mathrm{x}}$, the total hydroxyl radical

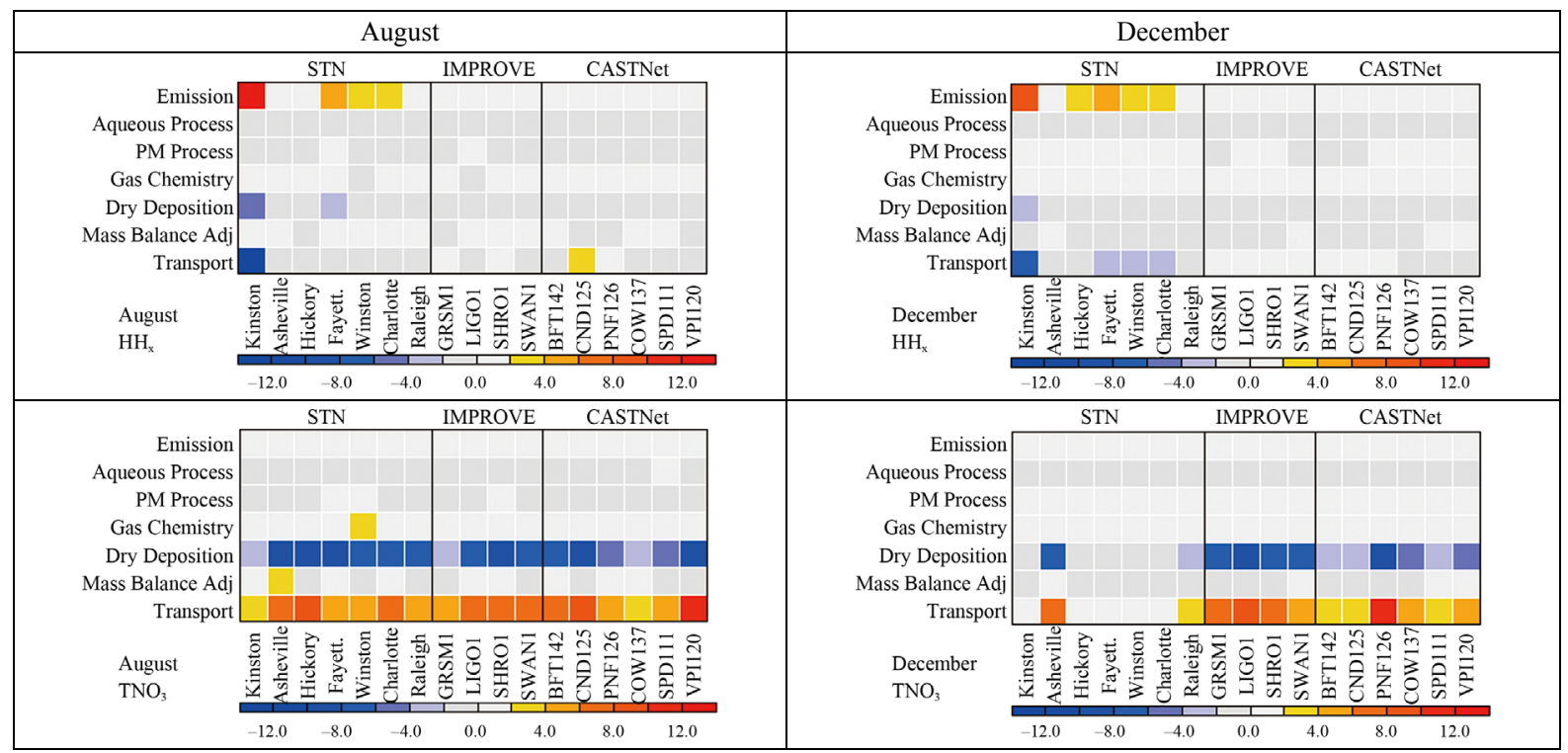

Figure 4. The monthly-mean process contributions to the surface concentrations of $\mathrm{NH}_{\mathrm{x}}$ in $\mathrm{ppb}^{\mathrm{h}} \mathrm{hr}^{-1} \mathrm{and} \mathrm{TNO}_{3}$ in $\mu \mathrm{g} \cdot \mathrm{m}^{-3} \cdot \mathrm{hr}^{-1}$ during August and December 2002. 


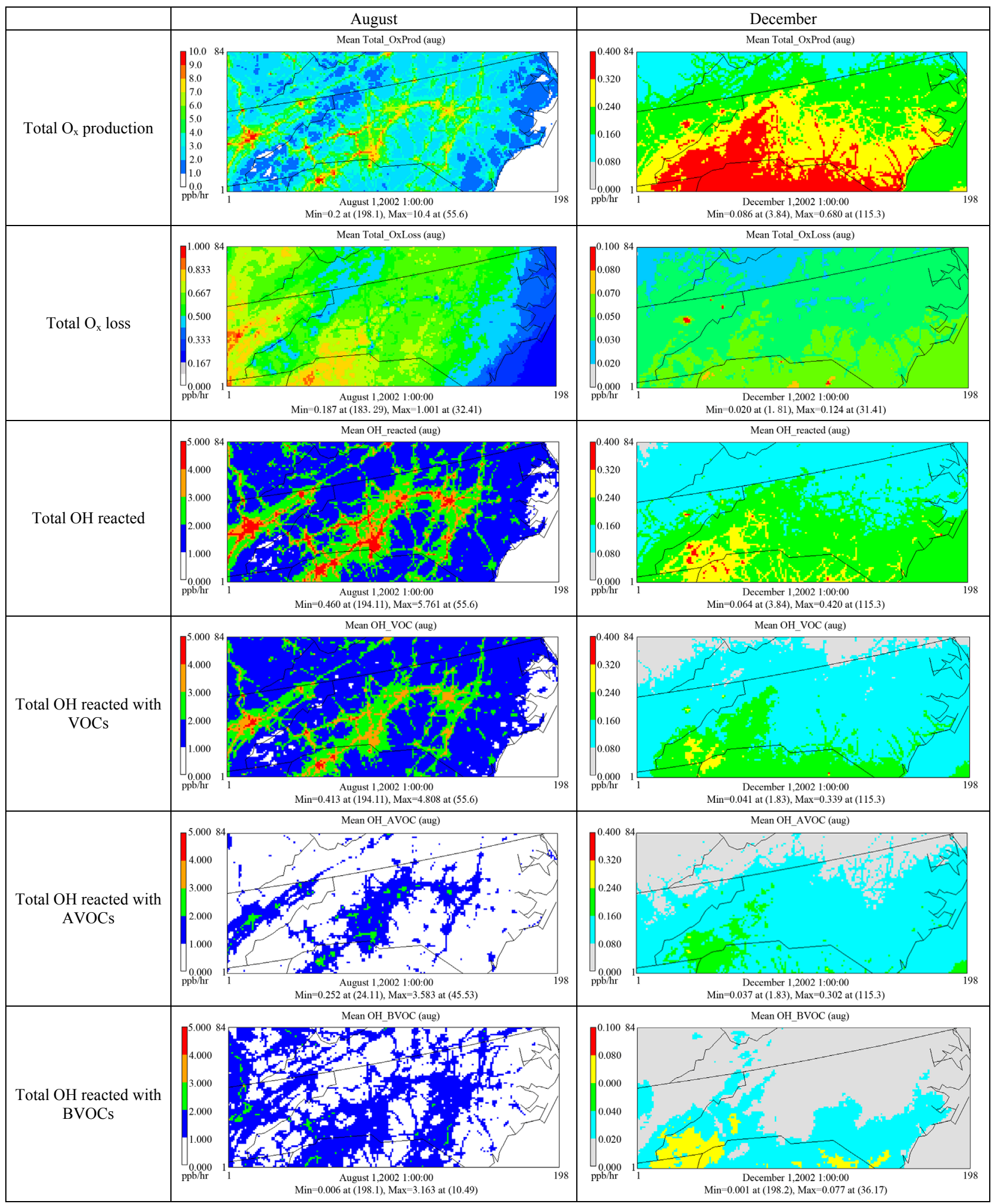

Figure 5. The spatial distribution of monthly-mean production and loss rates of $\mathrm{O}_{\mathrm{x}}$, total $\mathrm{OH}$ reacted, and total $\mathrm{OH}$ reacted with VOCs, AVOCs, and BVOCs in the surface layer in August and December 2002.

$(\mathrm{OH})$ reacted, the total $\mathrm{OH}$ reacted with volatile organic compounds (VOCs), anthropogenic VOCs (AVOCs), and biogenic VOCs (BVOCs) at the surface layer. A much higher total $\mathrm{O}_{\mathrm{x}}$ production indicates a much higher 
oxidation capacity in August than in December, leading to higher monthly-mean $\mathrm{O}_{3}$ mixing ratios as shown in Wu et al. [10]. The highest $\mathrm{O}_{\mathrm{x}}$ production concentrates in urban and suburban areas along the main highways such as highways I-40, I-95, I-85, I-77, and I-26 in the Piedmont and Mountains regions in August and over the southern portion of the domain in December. The loss of $\mathrm{O}_{\mathrm{x}}$ occurs in the Piedmont and Mountains regions where the emissions of $\mathrm{NO}_{\mathrm{x}}$ are high in August but spreads out the whole domain due to prevailing westerlies with relatively high wind speeds as reported in $\mathrm{Wu}$ et al. [10] that transport and mix the precursors of $\mathrm{O}_{\mathrm{x}}$ more uniformly in December. Similar to the spatial distributions of total $\mathrm{O}_{\mathrm{x}}$ production, the amount of $\mathrm{OH}$ reacted with major gases such as VOCs, $\mathrm{NO}_{\mathrm{x}}, \mathrm{SO}_{2}$, and carbon monoxide (CO) is much higher over urban and suburban areas along the main highways in the Piedmont and Mountains regions in August and over the southern portion of the domain, particularly in the southwestern NC and northwestern SC in December. Significant amounts of $\mathrm{OH}$ are consumed by VOCs in both months, with BVOCs in the rural and remote areas and a combination of AVOCs and BVOCs in urban and subareas areas.

Figure 6 shows the production and loss rates of $\mathrm{O}_{\mathrm{x}}$, $\mathrm{OH}$ reacted with AVOCs and BVOCs (referred to as $\mathrm{OH}-$ AVOCs and OH-BVOCs hereafter), the production of $\mathrm{NO}_{2}$ from the reactions involving hydroperoxy radicals $\left(\mathrm{HO}_{2}\right)$ and organic peroxy radicals $\left(\mathrm{RO}_{2}\right)$, and the productions of $\mathrm{HNO}_{3}$ due to the reaction of $\mathrm{OH}$ with $\mathrm{NO}_{2}$ and that of VOCs with nitrate radical $\left(\mathrm{NO}_{3}\right)$ at the 17 sites in both months. At all locations, $\mathrm{O}_{\mathrm{x}}$ production rates are higher than its loss rates by factors of $2.7-14.1$ in August and 4.9 - 10.7 in December. The production rate of $\mathrm{O}_{\mathrm{x}}$ is much higher at most STN sites (except for Kinston,

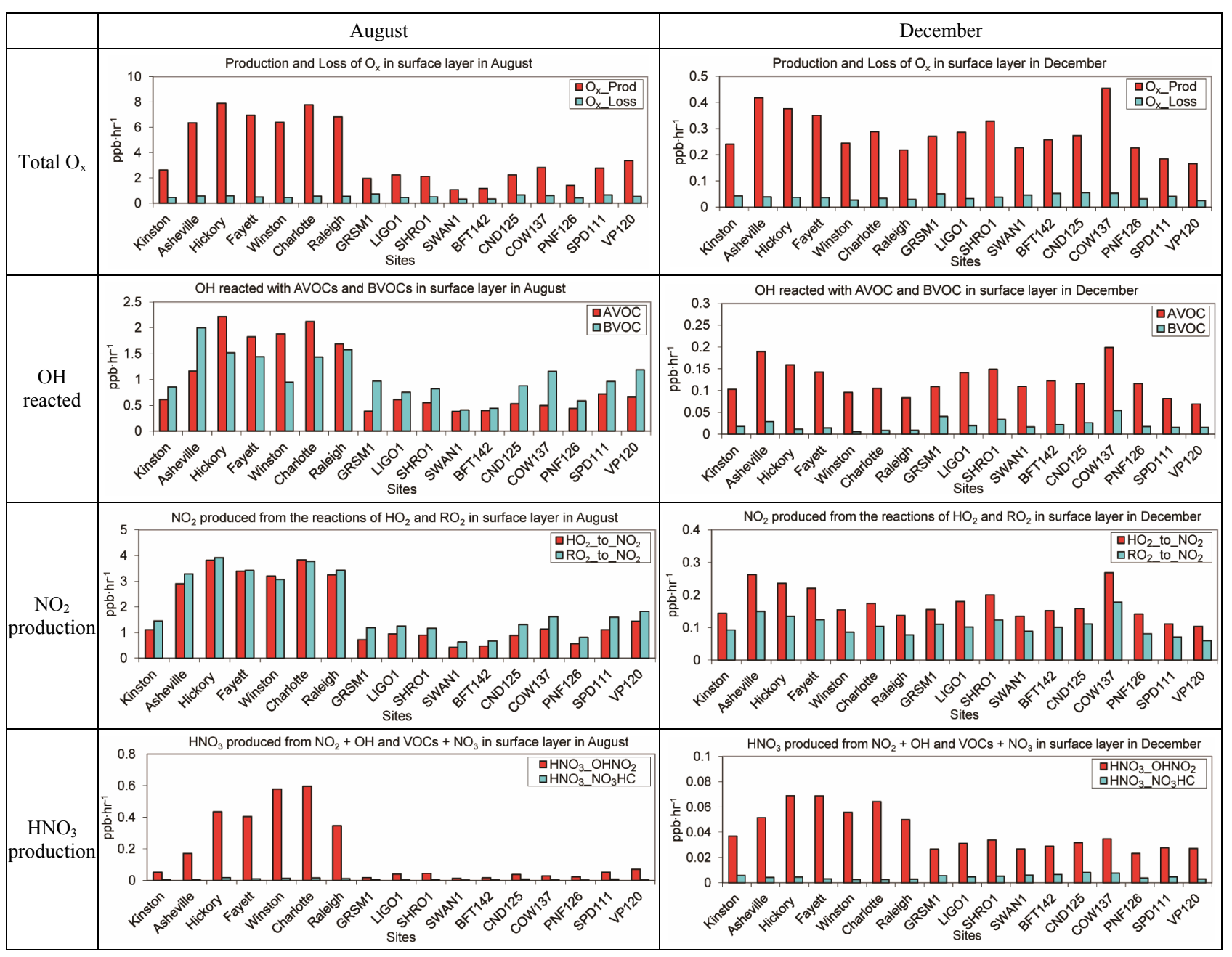

Figure 6. The monthly-mean production and loss rates of $\mathrm{O}_{\mathrm{x}}$, the rate of $\mathrm{OH}$ reacted with AVOCs and $\mathrm{BVOCs}$, the $\mathrm{NO}_{2}$ production rates by the reaction of $\mathrm{HO}_{2}$ and $\mathrm{RO}_{2}$, and the $\mathrm{HNO}_{3}$ production rates by the reactions of $\mathrm{OH}+\mathrm{NO}_{2}$ and $\mathrm{NO}_{3}+$ VOCs at seven STN sites: Kinston, Asheville, Hickory, Fayetteville, Winston-Salem, Charlotte, and Raleigh; four IMPROVE sites: GRSM1, LIGO1, SHRO1, and SWAN1; and six CASTNET sites: BFT142, CND125, COW137, PNF126, SPD111, and VPI120 in August and December 2002. 
which is an agricultural site with very high $\mathrm{NH}_{3}$ emissions located in Coastal Plain region) in August than other sites. In December, the production rates of $\mathrm{O}_{\mathrm{x}}$ at all sites are overall similar, with higher values at several mountain sites such as COW137, Asheville, and Hickory. The rates of $\mathrm{OH}-\mathrm{AVOCs}$ and $\mathrm{OH}-\mathrm{BVOCs}$ are much higher at all sites in August than in December. In August, the rates of $\mathrm{OH}-\mathrm{BVOCs}$ are higher than those of $\mathrm{OH}-$ AVOCs at all rural sites including Kinston, Asheville, GRSM1, LIGO1, SHRO1, SWAN1, BFT142, CND125, COW137, PNF126, SPD111, and VPI120, because of higher BVOCs emissions at these sites. In December, the rates of $\mathrm{OH}-A V O C s$ are higher than those of $\mathrm{OH}$ BVOCs at all sites. $\mathrm{O}_{3}$ is produced through the photolysis of $\mathrm{NO}_{2}$ followed by the reaction of atomic oxygen $(\mathrm{O})$ with molecular oxygen $\left(\mathrm{O}_{2}\right)$. Most $\mathrm{NO}_{2}$ come from the conversion of $\mathrm{NO}$ by $\mathrm{HO}_{2}$ and $\mathrm{RO}_{2}$ radicals. As shown in Figure 6, the amount of $\mathrm{NO}_{2}$ produced by the reactions involving $\mathrm{HO}_{2}$ is similar to that involving $\mathrm{RO}_{2}$ at all sites in August, with slightly higher production rates from the $\mathrm{NO}+\mathrm{RO}_{2}$ reaction at the rural sites than at the urban sites. It is, however, higher than that by the reactions involving $\mathrm{RO}_{2}$ in December. This indicates that VOCs contribute to $\mathrm{O}_{3}$ formation similarly to $\mathrm{NO}_{\mathrm{x}}$ in August, but less than that of $\mathrm{NO}_{x}$ due to a VOC-limited $\mathrm{O}_{3}$ chemistry in December. The production rate of $\mathrm{HNO}_{3}$ due to the reaction of $\mathrm{OH}$ with $\mathrm{NO}_{2}$ dominates over that due to the nighttime reactions of VOCs with $\mathrm{NO}_{3}$ radicals in both months, with much higher reaction rates of $\mathrm{OH}+$ $\mathrm{NO}_{2}$ (by up to a factor of 42.6) at urban sites than other sites in August and more uniform reaction rates of $\mathrm{OH}+$ $\mathrm{NO}_{2}$ (within a factor of 3 ) at all sites in December.

The ratio of the production rates of $\mathrm{H}_{2} \mathrm{O}_{2}$ and $\mathrm{HNO}_{3}$ $\left(\mathrm{PH}_{2} \mathrm{O}_{2} / \mathrm{PHNO}_{3}\right)$ is a useful indicator for $\mathrm{O}_{3}$ photochemistry that is calculated in IRRs. The threshold value of $\mathrm{PH}_{2} \mathrm{O}_{2} / \mathrm{PHNO}_{3}$ is 0.2 , values below which indicate a VOC-limited $\mathrm{O}_{3}$ chemistry and at or above which indicate a $\mathrm{NO}_{\mathrm{x}}$-limited chemistry $[14,15]$. The ratio of the mixing ratios of $\mathrm{H}_{2} \mathrm{O}_{2}$ and $\mathrm{HNO}_{3}\left(\mathrm{H}_{2} \mathrm{O}_{2} / \mathrm{HNO}_{3}\right)$ and $\mathrm{NO}_{\mathrm{y}}$ mixing ratios in the afternoon have also been frequently used as photochemical indicators, with a range of threshold values suggested by several studies accounting for differences in meteorological and chemical conditions for measurements or model configurations such as horizontal grid resolutions and airsheds used in modeling studies. For example, the threshold value proposed for $\mathrm{H}_{2} \mathrm{O}_{2} / \mathrm{HNO}_{3}$ was 0.2 by Sillman et al. [16], Tonnesen and Dennis [17], and Hammer et al. [18], 0.4 by Sillman [14], $0.8-1.2$ by Lu and Chang [19], and 2.4 by Zhang et al. [3]. The values of $\mathrm{H}_{2} \mathrm{O}_{2} / \mathrm{HNO}_{3}$ below these threshold values indicate a VOC-limited $\mathrm{O}_{3}$ chemistry, otherwise a $\mathrm{NO}_{\mathrm{x}}$-limited $\mathrm{O}_{3}$ chemistry. The threshold value proposed for $\mathrm{NO}_{\mathrm{y}}$ was 3 - $5 \mathrm{ppb}$ by Lu and Chang [19], $5 \mathrm{ppb}$ by Zhang et al. [3], 10 - 25 ppb by Milford et al. [20] and 20 ppb by Sillman [14]. The values of $\mathrm{NO}_{\mathrm{y}}$ larger than these threshold values indicate a VOC-limited $\mathrm{O}_{3}$ chemistry, otherwise a $\mathrm{NO}_{\mathrm{x}}$-limited $\mathrm{O}_{3}$ chemistry. Among these three photochemical indicators, $\mathrm{PH}_{2} \mathrm{O}_{2} / \mathrm{PHNO}_{3}$ has been the most robust one in both summer and winter months [3]. It is therefore selected as a benchmark to determine the robustness of $\mathrm{H}_{2} \mathrm{O}_{2} / \mathrm{HNO}_{3}$ and $\mathrm{NO}_{\mathrm{y}}$ as a photochemical indicator for $\mathrm{O}_{3}$ chemistry in this work.

Figure 7 shows simulated spatial distributions of three photochemical chemical indicators: $\mathrm{PH}_{2} \mathrm{O}_{2} / \mathrm{PHNO}_{3}, \mathrm{H}_{2} \mathrm{O}_{2} /$ $\mathrm{HNO}_{3}$, and $\mathrm{NO}_{\mathrm{y}}$ mixing ratios in the afternoon (noontime-6 pm) in both months. In August, the values of $\mathrm{PH}_{2} \mathrm{O}_{2} / \mathrm{PHNO}_{3}$ over most areas are above 0.2 , indicating a $\mathrm{NO}_{x}$-limited $\mathrm{O}_{3}$ chemistry. Those over urban and suburban areas are below 0.2 , indicating a VOC-limited $\mathrm{O}_{3}$ chemistry. Zhang et al. [3] performed a 1-year process analysis in 2001 using the PA tool in CMAQ over the continental US at a horizontal grid resolution of $36-\mathrm{km}$ and showed values of $\mathrm{PH}_{2} \mathrm{O}_{2} / \mathrm{PHNO}_{3}$ of $0.4-2.4$ over urban and suburban areas and higher values over the remaining areas in the simulation domain used in this study. Despite a different year (i.e., 2002) and emissions, the use of a much higher horizontal grid resolution of 4-km in this work shows a VOC-limited chemistry in urban and suburban areas that is not shown in the simulation at 36-km in Zhang et al. [3], demonstrating the benefit of the fine-scale modeling. The values $\mathrm{PH}_{2} \mathrm{O}_{2} / \mathrm{PHNO}_{3}$ are below 0.2 in December in nearly the whole domain, indicating a VOC-limited $\mathrm{O}_{3}$ chemistry, which is consistent with the $\mathrm{O}_{3}$ chemical regime in December 2001 obtained by Zhang et al. [3]. The comparison of this work and Zhang et al. [3] indicates that the predictions of $\mathrm{PH}_{2} \mathrm{O}_{2} /$ $\mathrm{PHNO}_{3}$ are highly sensitive to the horizontal grid resolution in summer but insensitive to it in winter. For $\mathrm{H}_{2} \mathrm{O}_{2} / \mathrm{HNO}_{3}$, all values are above 0.2 and nearly all values are above 2.4 in August, indicating a $\mathrm{NO}_{\mathrm{x}}$-limited chemistry that is consistent with that based on $\mathrm{PH}_{2} \mathrm{O}_{2} /$ $\mathrm{PHNO}_{3}$. In December, using a threshold value of 2.4 will indicate a VOC-limited $\mathrm{O}_{3}$ chemistry in most of the domain except for an area in the eastern $\mathrm{NC}$ in the Coastal Plain region, which is consistent with that based on $\mathrm{PH}_{2} \mathrm{O}_{2} / \mathrm{PHNO}_{3}$. For $\mathrm{NO}_{\mathrm{y}}$, in August, the threshold value of $10 \mathrm{ppb}$ gives similar VOC-limited $\mathrm{O}_{3}$ chemistry over urban and suburban areas and $\mathrm{NO}_{\mathrm{x}}$-limited $\mathrm{O}_{3}$ chemistry over remaining areas as compared to that indicated by $\mathrm{PH}_{2} \mathrm{O}_{2} / \mathrm{PHNO}_{3}$. In December, the lower the threshold value is, the more consistency can be obtained for areas with the VOC-limited $\mathrm{O}_{3}$ chemistry indicated by $\mathrm{PH}_{2} \mathrm{O}_{2} /$ $\mathrm{PHNO}_{3}$. The use of $5 \mathrm{ppb}$ as a threshold value indicates a VOC-limited chemistry over nearly the whole domain that is more consistent with the VOC-limited chemistry regime based on $\mathrm{PH}_{2} \mathrm{O}_{2} / \mathrm{PHNO}_{3}$ than the use of $10 \mathrm{ppb}$. These results indicate that $\mathrm{H}_{2} \mathrm{O}_{2} / \mathrm{HNO}_{3}$ and $\mathrm{NO}_{\mathrm{y}}$ are more robust indicators for $\mathrm{O}_{3}$ chemistry in summer than in 


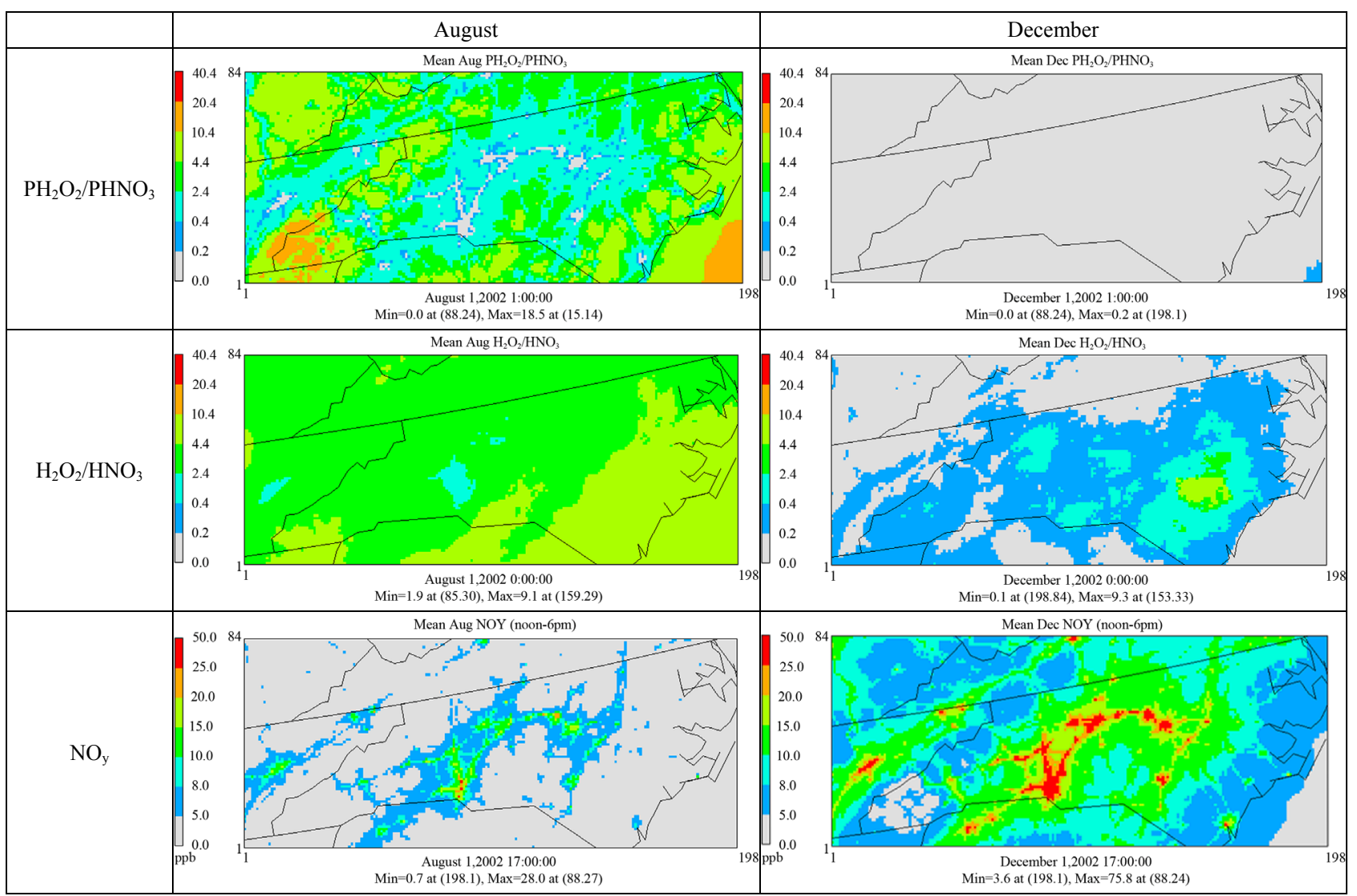

Figure 7. Simulated spatial distributions of monthly-mean $\mathrm{PH}_{2} \mathrm{O}_{2} / \mathrm{PHNO}_{3}, \mathrm{H}_{2} \mathrm{O}_{2} / \mathrm{HNO}_{3}$, and afternoon (noon-6 pm) $\mathrm{NO}_{\mathrm{y}}$ mixing ratios in August and December 2002.

winter, and a greater adjustment (e.g., adjusting the threshold value of $\mathrm{H}_{2} \mathrm{O}_{2} / \mathrm{HNO}_{3}$ from 0.2 to 11 (instead of suggested 2.4 by Zhang et al. [3]) and that of $\mathrm{NO}_{\mathrm{y}}$ from 20 ppb to $3 \mathrm{ppb}$ (instead of suggested $5 \mathrm{ppb}$ by Zhang et al. [3]) are needed make them more robust in indicating $\mathrm{O}_{3}$ chemistry regimes in winter.

Figure 8 shows the temporal variations of observed and simulated afternoon $\mathrm{NO}_{\mathrm{y}}$ mixing ratios and simulated $\mathrm{PH}_{2} \mathrm{O}_{2} / \mathrm{PHNO}_{3}$ at four sites in $\mathrm{NC}$ in August, 2002. Two threshold values (10 and $20 \mathrm{ppb}$ ) and one threshold value $(0.2 \mathrm{ppb})$ are also plotted for $\mathrm{NO}_{\mathrm{y}}$ and $\mathrm{PH}_{2} \mathrm{O}_{2} / \mathrm{PHNO}_{3}$, respectively, to help determine the $\mathrm{O}_{3}$ chemistry regimes. The simulated values of $\mathrm{PH}_{2} \mathrm{O}_{2} / \mathrm{PHNO}_{3}$ are above 0.2 at Kinston, indicating a $\mathrm{NO}_{\mathrm{x}}$-limited chemistry at this site. The simulated values of $\mathrm{PH}_{2} \mathrm{O}_{2} / \mathrm{PHNO}_{3}$ are mostly below 0.2 at Winston-Salem, Raleigh, and Charlotte, indicating a VOC-limited $\mathrm{O}_{3}$ chemistry. The observed and simulated afternoon $\mathrm{NO}_{\mathrm{y}}$ mixing ratios at Kinston agree well, and they are below $10 \mathrm{ppb}$, indicating a $\mathrm{NO}_{\mathrm{x}}$-limited chemistry at this site, consistent with the $\mathrm{O}_{3}$ chemistry regime results using $\mathrm{PH}_{2} \mathrm{O}_{2} / \mathrm{PHNO}_{3}$. About $50 \%$ of observed $\mathrm{NO}_{\mathrm{y}}$ values are below $10 \mathrm{ppb}$ and $99 \%$ of them are below $20 \mathrm{ppb}$. While the use of $20 \mathrm{ppb}$ indicates a $\mathrm{NO}_{\mathrm{x}}$-limited chemistry at these sites, the use of a $\mathrm{NO}_{\mathrm{y}}$ value of $10 \mathrm{ppb}$ or lower gives VOC-limited $\mathrm{O}_{3}$ chemistry regime that is more consistent with the $\mathrm{O}_{3}$ chemistry regime results obtained using $\mathrm{PH}_{2} \mathrm{O}_{2} / \mathrm{PHNO}_{3}$ during some afternoon hours. Compared with the observed $\mathrm{NO}_{\mathrm{y}}$, the simulated $\mathrm{NO}_{\mathrm{y}}$ values are higher during most hours at Winston-Salem, Raleigh, and Charlotte. About 25\% of simulated $\mathrm{NO}_{\mathrm{y}}$ values are below $10 \mathrm{ppb}$ and $60 \%$ of them are below $20 \mathrm{ppb}$. This indicates that simulated $\mathrm{NO}_{\mathrm{y}}$ may not be as robust as $\mathrm{PH}_{2} \mathrm{O}_{2} / \mathrm{PHNO}_{3}$ to indicate the $\mathrm{O}_{3}$ chemistry regime, because of inaccurate model predictions of $\mathrm{NO}_{\mathrm{y}}$.

\section{Summary}

The process analysis is performed at a horizontal grid spacing of 4-km over an area in the southeastern US that is centered over NC for August and December, 2002. Emissions provide a dominant source for primary pollutants such as $\mathrm{NH}_{3}, \mathrm{NO}$, and $\mathrm{SO}_{2}$, and an important source for some secondary pollutants such as $\mathrm{NO}_{2}$ at all sites in August and December. While transport acts as a major sink for these pollutants, it provides a major source for $\mathrm{HNO}_{3}$ and $\mathrm{O}_{3}$ at most sites. Dry deposition is an important sink for all these species, in particular, $\mathrm{HNO}_{3}$, $\mathrm{SO}_{2}$, and $\mathrm{O}_{3}$. Gas-phase chemistry may serve as a source 


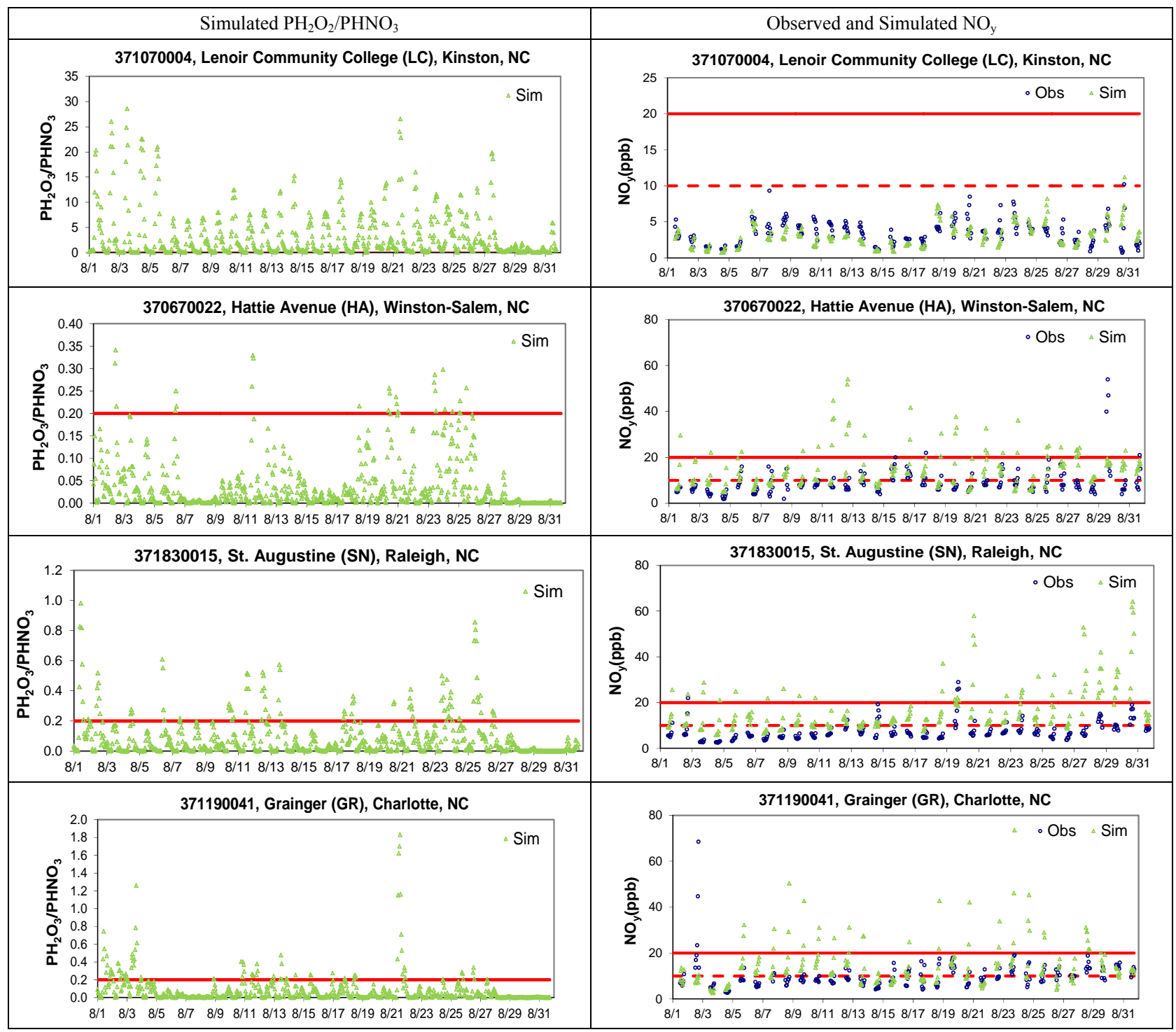

Figure 8. The temporal variations of simulated ratios of hourly production rates of $\mathrm{H}_{2} \mathrm{O}_{2}$ and $\mathrm{HNO}_{3}\left(\mathrm{PH}_{2} \mathrm{O}_{2} / \mathrm{PHNO}_{3}\right)$ and observed and simulated afternoon (noon-6 pm) NOy mixing ratios at four sites in NC in August 2002. The solid and dash lines indicate the original and adjusted threshold values, respectively.

for some species such as $\mathrm{NO}_{2}$ and $\mathrm{HNO}_{3}$ but a sink for other species such as $\mathrm{O}_{3}$ at urban and suburban sites and $\mathrm{NO}$ and $\mathrm{SO}_{2}$ at all sites. The roles of these processes in August and December are overall similar for gaseous pollutants, except that transport and dry deposition make larger contributions to $\mathrm{O}_{3}$ formation in August than in December. Emissions provide a dominant source for $\mathrm{PM}_{2.5}, \mathrm{SO}_{4}^{2-}, \mathrm{EC}, \mathrm{POA}$, and OIN, particularly at urban and suburban sites in both months. PM processes contribute to the formation of $\mathrm{PM}_{2.5}$ and $\mathrm{NO}_{3}^{-}$at the STN sites and SOA at most sites in December and the formation of $\mathrm{NH}_{4}^{+}$at all sites in August and most sites in December. They reduce $\mathrm{NO}_{3}^{-}$at most sites in August and at the IMPROVE and CASTNET sites in December as well as $\mathrm{PM}_{2.5}$ and SOA at most sites in August. In
August, transport provides a dominant sink for $\mathrm{PM}_{2.5}$ and most of its composition except for $\mathrm{NO}_{3}^{-}$and $\mathrm{SOA}$ at most STN sites, and it acts as a source for secondary inorganic $\mathrm{PM}$ such as $\mathrm{SO}_{4}^{2-}$ and $\mathrm{NO}_{3}^{-}$, and $\mathrm{SOA}$ at the IMPROVE and CASTNET sites. In December, transport provides a sink for all PM species at most STN sites but a source for most PM species at the IMPROVE and CASTNET sites. Dry deposition is an important sink for all PM species in both months. The fate of $\mathrm{NH}_{\mathrm{x}}$ is dominated by that of $\mathrm{NH}_{3}$, whereas the fate of $\mathrm{TNO}_{3}$ is dominated by that of $\mathrm{HNO}_{3}$.

The total $\mathrm{O}_{\mathrm{x}}$ production and loss, and the total $\mathrm{OH}$ reacted are much higher in August than in December, particularly at most STN sites, indicating a higher oxidation capacity in August than in December and at urban and 
suburban sites than at rural sites. The highest $\mathrm{O}_{\mathrm{x}}$ production and loss occur in urban and suburban areas in the Piedmont and Mountains regions but more uniformly throughout the simulation domain in December. The amount of $\mathrm{OH}$ reacted with major gases is much higher over urban and suburban areas in August and over the southern portion of the domain in December. Significant amounts of $\mathrm{OH}$ are consumed by BVOCs in the rural and remote areas and a combination of AVOCs and BVOCs in urban and subareas areas in both months. The rates of $\mathrm{OH}-\mathrm{BVOCs}$ are higher than those of OH-AVOCs at all rural sites in August because of higher BVOCs emissions but the opposite occurs in December. The amount of $\mathrm{NO}_{2}$ produced by the reactions involving $\mathrm{HO}_{2}$ is similar to that involving $\mathrm{RO}_{2}$ at all sites in August but higher than that by the reactions involving $\mathrm{RO}_{2}$ in December. The production rate of $\mathrm{HNO}_{3}$ due to the reaction of $\mathrm{OH}$ with $\mathrm{NO}_{2}$ dominates over that due to the nighttime reactions of VOCs with $\mathrm{NO}_{3}$ radicals in both months.

The values of $\mathrm{PH}_{2} \mathrm{O}_{2} / \mathrm{PHNO}_{3}$ indicate a $\mathrm{NO}_{\mathrm{x}}$-limited $\mathrm{O}_{3}$ chemistry over most areas in August and a VOC-limited $\mathrm{O}_{3}$ chemistry over all areas in December, which is consistent with previous studies [e.g., 3,9]. They also indicate a VOC-limited $\mathrm{O}_{3}$ chemistry in urban and suburban areas in the simulation domain in August that is not found in previous model simulations at a coarser grid resolution. The values of $\mathrm{PH}_{2} \mathrm{O}_{2} / \mathrm{PHNO}_{3}$ are highly sensitive to the horizontal grid resolution in summer but insensitive to it in winter. $\mathrm{H}_{2} \mathrm{O}_{2} / \mathrm{HNO}_{3}$ with a threshold value of 2.4 can indicate $\mathrm{O}_{3}$ chemistry regimes that are overall consistent with those based on $\mathrm{PH}_{2} \mathrm{O}_{2} / \mathrm{PHNO}_{3}$ over most of areas in both months. Simulated afternoon $\mathrm{NO}_{\mathrm{y}}$ with a threshold value of $10 \mathrm{ppb}$ indicates a similar $\mathrm{O}_{3}$ chemistry regime to that indicated by $\mathrm{PH}_{2} \mathrm{O}_{2} / \mathrm{PHNO}_{3}$ in August. Its threshold value in December may need to be adjusted to be below $5 \mathrm{ppb}$ to make it a more robust photochemical indicator. The $\mathrm{O}_{3}$ chemistry regimes indicated by $\mathrm{PH}_{2} \mathrm{O}_{2} / \mathrm{PHNO}_{3}$ at several sites are consistent with those indicated by observed afternoon $\mathrm{NO}_{\mathrm{y}}$ values at these sites when a threshold value of $10 \mathrm{ppb}$ or lower is used in August. When the simulated $\mathrm{NO}_{\mathrm{y}}$ values deviate significantly from observed $\mathrm{NO}_{\mathrm{y}}$ values, they may not be as robust as $\mathrm{PH}_{2} \mathrm{O}_{2} / \mathrm{PHNO}_{3}$ to indicate the $\mathrm{O}_{3}$ chemistry regime.

\section{Acknowledgements}

This work is supported by the National Research Initiative Competitive Grant no. 2008-35112-18758 from the USDA Cooperative State Research, Education, and Extension Service Air Quality Program. Thanks are due to Mike Abraczinskas, George Bridgers, Wayne Cornelius, and Karen Harris of NCDENR for providing VISTAS's emissions and CMAQ modeling results with a $12-\mathrm{km}$ grid spacing and Don Olerud, BAMS, for providing VISTAS's MM5 simulation results.

\section{REFERENCES}

[1] J.-C. C. Jang, H. E. Jeffries and S. Tonnesen, "Sensitivity of Ozone to Model Grid Resolution-II. Detailed Process Analysis for Ozone Chemistry," Atmospheric Environment, Vol. 29, No. 21, 1995, pp. 3101-3114. doi:10.1016/1352-2310(95)00119-J

[2] H. E. Jeffries and S. Tonnesen, "A Comparison of Two Photochemical Reaction Mechanisms Using Mass Balance and Process Analysis," Atmospheric Environment, Vol. 28, No. 18, 1994, pp. 2991-3003. doi:10.1016/1352-2310(94)90345-X

[3] Y. Zhang, X.-Y. Wen, K. Wang, K. Vijayaraghavan and M. Z. Jacobson, "Probing into Regional $\mathrm{O}_{3}$ and Particulate Matter Pollution in the United States: 2. An Examination of Formation Mechanisms through a Process Analysis Technique and Sensitivity Study," Journal of Geophysical Research, Vol. 114, No. D22, 2009, pp. 1-31. doi:10.1029/2009JD011900

[4] Y. Zhang, K. Vijayaraghavan and C. Seigneur, "Evaluation of Three Probing Techniques in a Three-Dimensional Air Quality Model," Journal of Geophysical Research, Vol. 110, No. D2, 2005, pp. 1-21. doi:10.1029/2004JD005248

[5] S. C. Yu, R. Mathur and K. Schere, "Evaluation of RealTime $\mathrm{PM}_{2.5}$ Forecasts and Process Analysis for $\mathrm{PM}_{2.5}$ Formation over the Eastern United States Using the EtaCMAQ Forecast Model during the 2004 ICARTT Study," Journal of Geophysical Research, Vol. 113, No. D6, 2008, pp. 1-20. doi:10.1029/2007JD009226

[6] S. C. Yu, R. Mathur, K. Schere, D. W. Kang and D. Tong, "A Study of the Ozone Formation by Ensemble Back Trajectory-Process Analysis Using the Eta-CMAQ Forecast Model over the Northeastern US during the 2004 ICARTT Period," Atmospheric Environment, Vol. 43, No. 2, 2009, pp. 355-363. doi:10.1016/j.atmosenv.2008.09.079

[7] K. Wang, Y. Zhang, C. Jang, S. Phillips and B. Wang, "Modeling Intercontinental Air Pollution Transport over the Trans-Pacific Region in 2001 Using the Community Multiscale Air Quality Modeling System," Journal of Geophysical Research, Vol. 114, No. D4, 2009, pp. 1-23. doi:10.1029/2008JD010807

[8] X.-H. Liu, Y. Zhang, J. Xing, Q. Zhang, K. Wang, D. G. Streets, C. J. Jang, W.-X. Wang and J.-M. Hao, "Understanding of Regional Air Pollution over China Using CMAQ: Part II. Process Analysis and Ozone Sensitivity to Precursor Emissions," Atmospheric Environment, Vol. 44, No. 20, 2010, pp. 3719-3727. doi:10.1016/j.atmosenv.2010.03.036

[9] P. Liu, Y. Zhang, S. C. Yu and K. L. Schere, "Use of a Process Analysis Tool for Diagnostic Study on Fine Particulate Matter Predictions in the US. Part II: Process Analyses and Sensitivity Simulations," Atmospheric Pollution Research, Vol. 2, No. 1, 2010, pp. 61-71. doi:10.5094/APR.2011.008

[10] S.-Y. Wu, S. Krishnan, Y. Zhang and V. Aneja, "Model- 
ing Atmospheric Transport and Fate of Ammonia in North Carolina, Part I. Evaluation of Meteorological and Chemical Predictions," Atmospheric Environment, Vol. 42, No. 14, 2008, pp. 3419-3436. doi:10.1016/j.atmosenv.2007.04.031

[11] G. A. Grell, J. Dudhia and D. R. Stauffer, "A Description of the Fifth Generation Penn State/NCAR Mesoscale Model (MM5)," National Center for Atmospheric Research, Boulder, 1994.

[12] M. R. Houyoux, J. M. Vukovich, C. J. Coats Jr., N. W. Wheeler and P. S. Kasibhatla, "Emission Inventory Development and Processing for the Seasonal Model for Regional Air Quality (SMRAQ) Project," Journal of Geophysical Research, Vol. 105, No. D7, 2002, pp. 90799090. doi:10.1029/1999JD900975

[13] D. W. Byun and K. L. Schere, "Review of the Governing Equations, Computational Algorithms and Other Components of the Models-3 Community Multiscale Air Quality (CMAQ) Modeling System," Applied Mechanics Reviews, Vol. 59, No. 2, 2006, pp. 51-77. doi:10.1115/1.2128636

[14] S. Sillman, "The Use of $\mathrm{NO}_{\mathrm{y}}, \mathrm{H}_{2} \mathrm{O}_{2}$, and $\mathrm{HNO}_{3}$ as Indicators for Ozone- $\mathrm{NO}_{\mathrm{x}}-\mathrm{Hydrocarbon}$ Sensitivity in Urban Locations," Journal of Geophysical Research, Vol. 100, No. D7, 1995, pp. 4175-4188. doi:10.1029/94JD02953

[15] G. S. Tonnesen and R. L. Dennis, "Analysis of Radical Propagation Efficiency to Assess Ozone Sensitivity to Hydrocarbons and $\mathrm{NO}_{\mathrm{x}} 1$. Local Indicators of Instantaneous Odd Oxygen Production Sensitivity," Journal of Geophysical Research, Vol. 105, No. D7, 2000, pp. 92139225. doi:10.1029/1999JD900371
[16] S. Sillman, D. He, C. Cardelino and R. E. Imhoff, "The Use of Photochemical Indicators to Evaluate Ozone- $\mathrm{NO}_{\mathrm{x}}$ Hydrocarbon Sensitivity: Case Studies from Atlanta, New York, and Los Angeles," Journal of the Air \& Waste Management Association, Vol. 47, No. 10, 1997, pp. 642652. doi:10.1080/10473289.1997.10464407

[17] G. S. Tonnesen and R. L. Dennis, "Analysis of Radical Propagation Efficiency to Assess Ozone Sensitivity to Hydrocarbons and $\mathrm{NO}_{\mathrm{x}}$ : 2. Long-lived Species as Indicators of Ozone Concentration Sensitivity," Journal of Geophysical Research, Vol. 105, No. D7, 2000, pp. 9227 9241. doi:10.1029/1999JD900372

[18] M.-U. Hammer, B. Vogel and H. Vogel, "Findings on $\mathrm{H}_{2} \mathrm{O}_{2} / \mathrm{HNO}_{3}$ as an Indicator of Ozone Sensitivity in Baden-Württemberg, Berlin-Brandenburg, and the Po Valley Based on Numerical Simulations," Journal of Geophysical Research, Vol. 107, No. D22, 2002, pp. LOP 3-1LOP 3-18. doi:10.1029/2000JD000211

[19] C.-H. Lu and J. S. Chang, "On the Indicator-Based Approach to Assess Ozone Sensitivities and Emissions Features," Journal of Geophysical Research, Vol. 103, No. D3, 1998, pp. 3453-3462. doi:10.1029/97JD03128

[20] J. B. Milford, D. F. Gao, S. Sillman, P. Blossey and A. G. Russell, "Total Reactive Nitrogen $\left(\mathrm{NO}_{\mathrm{y}}\right)$ as an Indicator of the Sensitivity of Ozone to Reductions in Hydrocarbon and $\mathrm{NO}_{\mathrm{x}}$ Emissions," Journal of Geophysical Research, Vol. 99, No. D2, 1994, pp. 3533-3542. doi:10.1029/93JD03224 